\title{
The Application of Microlecture in College English Teaching Process in China
}

\author{
Yang Song \\ Foreign Language Teaching Department, Yantai Nanshan University, Yantai, China \\ Email: ys_sonia@163.com
}

Received 31 May 2016; accepted 18 June 2016; published 24 June 2016

Copyright (C) 2016 by author and OALib.

This work is licensed under the Creative Commons Attribution International License (CC BY). http://creativecommons.org/licenses/by/4.0/

(C) (i) Open Access

\begin{abstract}
Since the year 1978 English has begun to be a compulsory course in most Chinese University; over the past several decades the teaching method of English courses was basically dependent on the traditional lecture form. As the rapid development of information technology, traditional Chinese English teaching mode has lost the attraction for young learners. Therefore, an innovative change is desired in English teaching area in Chinese colleges to adapt to the trend of social development. Meanwhile, the use of microlecture in the western world has installed new inspiration to China's English teaching. This thesis is based on the study of former relevant researches and teaching cases of microlecture, aiming to provide thinking angels for teaching reform and innovation in Chinese colleges.
\end{abstract}

\section{Keywords}

Microlecture, English Teaching, Application, Innovative, Information Technology

Subject Areas: Education, Linguistics

\section{Introduction}

The definition of microlecture given by Wikipedia is actual instructional content that is formatted for online and mobile learning using a constructivist approach. More specifically, as described in the Chronicle of Higher Education, these are approximately 60 second presentations with a specific structure. They are not just brief (one minute) presentations. The concept of microlecture is initiated by David Penrose, a senior teaching designer and College online service manager in America New Mexico San Juan College in 2008. David Penrose is called the One Minute Professor and he calls the microlecture "Knowledge Burst". Since then, microlecture as a teaching method not only was widely used in the United States, but also begun to spread to the rest of the world.

By the time microlecture came to China, the length of microlecture has been extended from 60 seconds to around 5 - 8 minutes, normally no more than 10 minutes. The length is not the only thing that was adjusted; as 
many other new things from abroad, it has to adapt to China's national conditions. Consequently, the concept of microlecture is redefined.

Microlecture refers to the informatization instruction design meticulously, in the form of streaming media showing around certain knowledge or teaching conducting short, complete teaching activities that promote the learners' autonomous learning to get the best effect [1].

It is filmed and uploaded to the network platform, convenient for learners to study. With the development of society, the arrival of the mobile Internet time directly changed the way people get information. The speeding up of the pace of life and the popularity of smart phones caused the reading fragmentation for Chinese people. According to the survey of the Chinese academy of press and publication, the rate of digital reading in 2014 is $58.1 \%$ which is 8.0 percentage point risen from 50.1\% in 2013. Digital reading rate exceeded traditional book reading rate for the first time. Along with the diversification of university curriculum, more colorful campus life, in addition to the complete compulsory professional course, students also have to take course that are interesting and helpful to their personal development [2]. English as a public basic course, its learning style, and learning time are increasingly facing challenge. The emergence of microlecture adapted the social development trend and people's reading habit. It is a brand new way to disseminate and teach knowledge. As a new type of teaching resources, microlecture provides a new method for both students and teachers. It also has a profound impact on traditional college English teaching model, teachers' professional skills as well as the relationship between teachers and students.

This thesis is going to analyze the use and practical cases of microlecture in the process of China's English teaching in the university, hopefully to provide a train of thought and merge the microlecture into the conventional teaching mode, and to promote China’s English teaching in universities.

\section{The Function of Microlecture in Collage English Teaching}

"Learning community", refer to a community that is formed by a learner and its helper (including teachers, expert, counselor etc.), they often communicate and share all kinds of learning resources in the process of learning, interchange each other's emotion, experience and ideas, complete certain learning tasks together. In the community, members influence each other and gain mutual promotion [3]. Both students and teachers are the subject of learning. The impact of microlecture is mutual. In addition to students and teachers, the traditional teaching model is being shocked and challenged at the same time.

\subsection{Promote the Learners' Autonomous Learning}

College students have enough time and sufficient space to seek for personal development, hence self-planning and self-management have significant meaning for them. Yet, only about one over ten of the students tend to autonomous learning, about $90 \%$ of the students hope to be able to under the guidance of the teacher or lectures. Moreover, their ability of self-discipline is weak, nearly half the students in the classroom learning efficiency is fairly low [4].

Microlecture, relative to traditional lecture, is tremendously short. Students could be able to finish one microlecture in one short period of their fragmentation free time. Each microlecture is about one single topic or one knowledge point; it is suitable for students to learn by themselves. As the form of microlecture is multimedia, such leaning style is more like personal tailor of knowledge; students have complete autonomy of the start point and the end point according to their own status. In this case, microlecture can both save time and get full use of time.

Another advantage for microlecture to promote the learners' autonomous learning is that by using the internet, students could find resources that they are interested in, and watch other teacher's microlecture, other than the teacher that the college arranged for them. By doing this students could have a chance to be capable of "extracts piths from others”, which also coincide with Chinese traditional academic culture.

The way students learn microlecture by themselves, their ability of finding problem, analyzing problem and solving problem will be developed in a considerable degree. Consequently, realize promotion of college student's autonomous learning.

\subsection{Promote Teachers' Professional Skills}

The appearance of microlecture brought in new opportunities and challenges for college English teaching. Its 
resources provides a new breakthrough for college English teaching model reform, new mode of microlecture environment of college English teaching possesses the characteristics of flexibility, timeliness, openness, modularized and lively, it is conducive to the students' individualized learning. Meanwhile, it is bound to cause the college English teachers to think about and reposition their role in teaching [5].

On one hand, in the time of microlecture, students and teachers are on an equal status. Students have a good chance to obtain certain knowledge ahead of teachers. In this case, it is urgent for teachers to keep stay at the forefront of this trend, broaden horizon and expend knowledge, so that to prepare for the role reversal. Teachers are not only the educators but also guide, supervisor and helper.

On the other hand, college teachers should keep up with the trend of the era development and renew their skills to deal with the information technology which is essential for microlecture. To present a microlecture, a variety of skills is vital. Despite the teaching process design ability, teaching ability and class control ability, the ability of using high technology equipment and editing is also necessary for teachers.

Under the background of information of microlecture teaching on teachers put forward new requirements, also cause deep thinking on their own professional development about teachers, there are multiple ways about teacher professional development, in these ways, there are conflicts between the micro-course teaching and the professional development of teachers, but also there is positive teacher professional development significance in the collision [6].

\subsection{The Effect to the Traditional Teaching Model}

In the traditional teaching mode, teaching content usually includes all kinds of knowledge points, the teacher usually choose verbal teaching mode to impart the knowledge, students are in an extremely passive position during the whole process of higher education [7]. Moreover the traditional teaching mode is generally dull and boring; it is a reasonable present situation that students have difficulties to understand the relevant knowledge. Under this kind of educational mode, students barely have any chance to seek for their self-development. As a result, the teaching and learning efficiency are also affected to some extent. Any improper behavior may cause the teaching link trapped in a vicious cycle. In addition, in the traditional teaching mode teaching resources are fixed, which makes the students' physical and mental freedom limited by a certain extent, generally it has a negative effect on their academic promotion.

In stark contrast, microlecture knowledge transfer process is diversified, normally through visual images, sound, animation, text reflects and emotional factors, help students to think and understand the knowledge point, compared with the traditional textbooks and homework, easier to grasp the difficulty and key points, conform to the students' learning habits [8]. Microlecture is the product of information age in the field of education, it made up for the inadequacy of traditional teaching form, it is an extension of the traditional teaching [9].

As to the form, traditional teaching mode has development for over one hundred years; the main form is students listening to the teacher's lecture. Unlike western universities, the courses in most China's college have no seminars as replenishment to the lecture. There is no support for students to deal with the large number of information that is given during the lecture. Microlecture is a perfect supplement to this. It can be a data for students to preview before the lecture or review after the lecture.

As to the content, the integrated use of text, images, sound, and animation technology, microlecture has the characteristics of vivid image, which is useful to improve the students' interest in learning. The content of knowledge is not limited within the scope of a textbook. On the contrary, it greatly expands the learning content.

\section{The Process of Prepare for a Microlecture}

Making microlectures are the process of micro research, teachers find problems in the practical teaching, they analyze problems, solve problems and make the process into microlectures, simple and practical. Making a microlecture is a process of teaching reflection; it can effectively promote the professional growth of teachers. The following is the process of preparing a entry in the first national Universities micro-teaching competition (Two Most Pressing Environmental Issues, work of Zhaojun Chen from Yantai Nanshan University).

\subsection{Analysis of Students}

The teaching object is sophomore students who have stronger learning interest and learning enthusiasm, good 
ability to independently learn, constantly-developing consciousness of practicing knowledge learnt, materialization and rationalization of individual values and social responsibility and strong motivation of learning English, so the teaching theme could attract students' interest to learn, so as to create stronger learning motivation.

\subsection{Analysis of Teaching Contents}

The first intensive reading text of Unit 1 in Experiencing English Integrated Course book III (Version 2) is Care for Our Mother Earth, the topic of which is related to caring earth and protecting environment, in the text, each environmentalist mainly talks about the greatest threat to environment, two main factors of environmental crisis as well as necessity and measures of protecting environment and earth when interviewed by journalist.

The teaching theme is described in the second paragraph of the text content, which mainly describes how environmentalist analyzes the two main factors of environmental crisis, the two main factors are tree felling and global warming, which are very conforming to the current situation, so students are conducive to think about environmental crisis and environmental protection, this is the teaching difficult point.

There are a lot of new words in the teaching content, but the syntactic structure is not complicated, only participle structures are used in the simple sentences, so the students could master the sentence meaning only by overcoming the new words from the language hierarchy, and the sentences are suitable for the students to read, this could supplement the students' oral and writing material, this is the teaching difficult point.

\subsection{Analysis of Teaching Object}

1) Knowledge Object (Overt Object): Reading the text could help the students to master the words and sentence structure.

2) Language Skill (Overt Object): Reading the text could help the students to describe and discuss the tree telling and global warming topics in English, so as to improve the oral English ability.

3) Moral Object (Concealed Object):

a) Improve the students' consciousness of caring earth and protecting environment.

b) Fostering the critical thinking of the students and strength the analysis and the judgment of the students on environmental crisis from the view of relations between trees and carbon dioxide, carbon dioxide and global warming, etc.

\subsection{The Selection and Utilization of Teaching Strategies and Teaching Steps}

The teaching Strategies adopt the combination of the direct method with multi-media tools.

The teaching method is based on the application of Direct Method. Through searching the pictures related to the tree felling, global warming, tree function and greenhouse gas emission online, and matching corresponding words for the pictures according to the text content, the multi-media PPT courseware is made.

The teaching topic of environment and earth is suitable for the multi-media courseware to present; the multimedia courseware has the advantages of deep impression and large information. The teacher could directly present and combine the pictures and the English words via the multi-media, so as to carry the further creative utilization which could process the concrete meaning and the abstract meaning of the intensive reading into images that are more visual and easier for students to accept, students could utilize the pictures to assist the memory of the text content via association (which solve the teaching difficult point), so that the students could improve constantly the integrated ability of English language. The teaching steps are designed as follows (Table 1).

\subsection{Teaching Summary and Reflection}

Direct method is applied in the college English intensive reading class, the teacher shall exert "general type" exemplary demonstration, only via this, the students could respect teachers, activate their English learning interest, follow closely the teacher's step, and memory the English sentences, thereby well understanding text meaning, improving the English presentation skill, and accumulating the English materials in the brain, so that the students could achieve flexible application of English in the later studying, and avoiding the phenomenon that the students have nothing to speak due to the limited English knowledge.

The students could actively learn English with the help of the relation among the pictures by putting the 
Table 1. Design of teaching steps.

\begin{tabular}{|c|c|c|c|c|}
\hline Teaching Step & Teaching Content & Teaching Method & Media & Interactive Mode \\
\hline 1. Question introduction & $\begin{array}{l}\text { According to the text content, } \\
\text { the question is directly } \\
\text { raised out, for example: } \\
\text { According to Walter Semkiw, } \\
\text { what environmental issues } \\
\text { do you find most pressing? }\end{array}$ & $\begin{array}{l}\text { Discussion } \\
\text { method }\end{array}$ & PPT, pics & $\begin{array}{l}\text { Students answer the } \\
\text { question according } \\
\text { to the pictures }\end{array}$ \\
\hline $\begin{array}{l}\text { 2. The utilization } \\
1 \text { of direct method }\end{array}$ & $\begin{array}{l}\text { The teacher directly combines the } \\
\text { English content with the pictures } \\
\text { in the tree felling paragraph, and } \\
\text { guides the students to read and retell. }\end{array}$ & $\begin{array}{l}\text { Direct method, } \\
\text { Demonstrative } \\
\text { simulation } \\
\text { method }\end{array}$ & PPT, pics & $\begin{array}{c}\text { Students read after } \\
\text { the teacher and retell, } \\
\text { and master important words }\end{array}$ \\
\hline $\begin{array}{l}\text { 3. The utilization } \\
\text { of direct method }\end{array}$ & $\begin{array}{l}\text { The teacher directly combines the } \\
\text { English content with the pictures } \\
\text { in the global warming paragraph, } \\
\text { and guides the students to read and retell. }\end{array}$ & $\begin{array}{l}\text { Direct Method, } \\
\text { Demonstrative } \\
\text { simulation } \\
\text { method }\end{array}$ & PPT, pics & $\begin{array}{l}\text { Students read after the } \\
\text { teacher and retell, } \\
\text { and master important words }\end{array}$ \\
\hline 4. Brainstorming & $\begin{array}{l}\text { Combining with the description } \\
\text { of the environmentalist, the teachers } \\
\text { sublime the text content and raise } \\
\text { the question, for example: How do } \\
\text { you think of the relationship between } \\
\text { deforesting and global warming? }\end{array}$ & $\begin{array}{l}\text { Discussion } \\
\text { method }\end{array}$ & PPT, pics & $\begin{array}{l}\text { According to the learned } \\
\text { two main factors and } \\
\text { self-understanding, } \\
\text { students answer } \\
\text { the question }\end{array}$ \\
\hline 5. After-class tasks & $\begin{array}{l}\text { The teacher arranges the students } \\
\text { to listen "Earth Song” by Michael } \\
\text { Jackson, and let the students } \\
\text { to discuss how to care the earth. }\end{array}$ & & videos & $\begin{array}{l}\text { The students shall think } \\
\text { out the measures how to care } \\
\text { the environment according } \\
\text { to the MV and lyric as well as } \\
\text { the text and reality }\end{array}$ \\
\hline
\end{tabular}

walking stick of Chinese aside, so that the language intuition and the English thinking abilities of the students could be fostered, thereby immersing into the conception created by the English words, experiencing the charm of the English expression and enjoying the English learning interest and achievement. The teacher could use passion to guide the lesson, and the students' blood of actively learning could be burned.

\section{Limitations of Microlecture}

Dialectical look at things, see both sides of a thing. There are three points of limitation of microlecture.

Firstly, microlecure lacks of interaction between teachers and students. Teaching process is not only a process of imparting knowledge, is also the process of emotional communication [10]. Learn through microlecture individually ignored the connection between teachers and students emotionally. The learning atmosphere cannot compare with learning in an actual class, more or less lower the efficiency of learning. It seems quite difficult to accelerate each other between teaching and learning.

Secondly, microlecture lacks of integrity in knowledge transfer process. Microlecture is short; each knowledge point could be one individual microlecture. A whole learning system was cut into pieces. It is keeping pace with the fragments of learning but ruining systematization of learning.

Thirdly, microlecture also lacks of regulation during the leaning process. Under the influence of traditional education for a considerable long time, a great number of Chinese college students are lack of independence and the ability of self monitoring. Character of the basement on new information technology and the mobile terminal determines its uncontrollability.

\section{Conclusion}

Nowadays, because the knowledge update speed is increasingly high, the traditional teaching mode provides a relatively small amount of information in class, which is difficult to meet the students' growing demand. Both microlecture and traditional teaching methods have their own advantages and disadvantages; therefore, combining them together organically is increasingly urgent; they might find a way to complement each other. This me- 
thod can overcome the insufficient information shortage of traditional teaching method and enhance the emotional connection between teachers and students [11]. In consequence, fused microlecture and traditional teaching mode complement each other: promoting microlecture teaching with the traditional teaching concept; assisting traditional teaching by microlecture teaching. It is helpful to stimulate students' interest in learning, and cultivate students' ability of active learning and active thinking.

\section{Acknowledgements}

This paper is supported by “ESP Teachers' Classroom Multimodal Discourse Analysis” (No: J15WD50), one of Projects for Humanities and Social Sciences of Scientific Research Development Program for Colleges and Universities in Shandong Province.

\section{References}

[1] Zhang, Y.C. (2013) Microlecture Construction Research and Thinking. China Education Network, 10, 1-2.

[2] Xu, X.Q. (2016) Fragmentation Learning of College English from the Perspective of Big Data. Journal of Bengbu University, 5, 95-98.

[3] Qi, D. (2004) Research and Design of Web-based Learning Community. Master's Degree Thesis, Northeast Normal University, 4-5.

[4] Duan, S.F. and Zhang, M.H. (2015) Influence on the Teachers’ Teaching Behavior and Students' Learning Behavior Caused by "MOOCs" and "MCOVs" in the Independent College. Value Engineering, No. 29, 187-189.

[5] Gan, L.L. (2015) On the New Roles of College English Teachers Based on Micro Class Context. Journal of Hunan Industry Polytechnic, 15, 68-70.

[6] Ye, D.P. (2014) Micro-Course Teaching and Teacher Professional Development under the Background of Information. Journal of Bijie University, 32, 107-110.

[7] Pu, X.L. (2015) Use of "Micro Class" Open Platform to Promote the Rapid Growth of Young Teachers. The Guide of Science \& Education, No. 6, 68-69.

[8] Wei, J. and Sang, X.F. (2015) Discrimination of Micro Course and the Exploration of the Practical Connotation. Education Modernization, No. 17, 163-168.

[9] Jin, Y. and Meng, Y. (2015) A Research on Combination of the Micro Course and the Traditional Classroom to Cultivate Student's Abilities of Workplace Practical English. Overseas English, No. 20, 56-57.

[10] You, Y. (2015) A Brief Analysis on the Integration of Micro Teaching and Traditional Teaching. Informatization Construction, No. 6, 191.

[11] Xu, C.F. and Guo, Q. (2014) The Theory of Micro Lessons and Effective Integration of Traditional Teaching. Career Horizon, No. 1, 74-76.

\section{Warmly welcome your paper submission to OALib Journal!}

- Publication on a daily basis

- 9 subject areas of science, technology and medicine

- Fair and rigorous peer-review system

- Fast publication process

- Article promotion in various social networking sites (LinkedIn, Facebook, Twitter, etc.)

- Widely-targeted and multidisciplinary audience to read your research

Submit Your Paper Online: Click Here to Submit

Contact Us: service@oalib.com 